\title{
Marketing and Constraints Analysis of Pomegranate in Solapur District of Maharashtra
}

\author{
G.D. Rede" and K. Bhattacharyya \\ Department of Agricultural Economics, BCKV, Mohanpur, West Bengal, India \\ *Corresponding author: ganeshrede3156@gmail.com
}

\begin{abstract}
Increased production of agricultural commodities would be of no worth, if efficient marketing does not follow it. Marketing of agricultural products usually signifies their physical transfers as well as the commercial terms on which the transfers are made. The pomegranate produce in the study area was marketed through three different channels from producers to ultimate consumer's viz., Channel- I: FarmerPre-harvest contractor -Commission agent cum wholesaler - Retailer -Consumer, Channel-II: FarmerDistant Market wholesaler- Retailer -Consumer and Channel-III: Farmer - Exporter. Channel- I was the most popular channel of marketing in the study area, since in this channel the net price received by the producer was higher than other channels. Also due to the presence of harvest contractor in channel-I, time and transportation cost of the producer were saved and moreover advance payment by the pre-harvest contractor before taking the delivery of the produce was also the reason for the popularity of Channel-I. Garrett ranking technique has been used to analyze the marketing problems faced by the pomegranate farmers. Majority of the farmers opined that they did not get remunerative price for the produce and are also cheated by the middlemen, higher transportation costs when fruits are sold outside the local area, high commission charges, lack of market information and low price paid to farmers.
\end{abstract}

Keywords: Pomegranate, marketing, channels, cost, margin, constraints, Garrett ranking

In marketing of agricultural products, forming an equilibrium between supply and demand in various phases of production to ultimate consumption soothes farm income and fulfils consumer demand. So, agricultural marketing study seems essential. (Kohansal and Rahimi, 2013). In the production of pomegranate, marketing plays an important role. When the farmers cultivate this fruit crop mainly for markets, they are attentive to know the profitable crop at the prevailing prices in the market at which the produce would be sold. Maharashtra state is popularly known as the 'fruit bowl' of India. (Kunthe, 2006). Pomegranate is the main fruit crop grown in Maharashtra state. This crop is characterized by high productivity per unit area with higher incomes and comparatively low water requirement. Pomegranate is mainly cultivated in the draught prone area of Maharashtra state, which includes Solapur, Sangli, Nashik,
Ahmednagar, Pune, Dhule, Aurangabad, Satara, Osmanabad, and Latur districts. Solapur district is a drought-prone district. For such a drought-prone area, pomegranate is a beneficial crop. Area under Pomegranate cultivation and growth rate is higher in the study region, it is due to the profitability of pomegranate crop. In pomegranate farming, factors like market, producer and consumers decide the marketing cost of pomegranate fruits. Growers necessarily get benefit as per the production cost. But unfortunately growers get less profit due to large number of marketing intermediaries in marketing process. An attempt has been made to analyze marketing costs, margins and price spread of pomegranate fruit in the study region with the following specific objectives:

1. To workout marketing costs, margins and price spread for different channels of pomegranate marketing. 
2. To analyze marketing problems faced by pomegranate cultivators.

\section{METHODOLOGY}

In the present dissertation work, the required data were collected for the year 2014-15 in Solapur district of Maharashtra. Data were collected from primary sources to achieve the stated objectives. Primary data have been collected from the selected pomegranate cultivators with intensive visits at farm level through personal interviews with the help of well-structured and pre-tested schedules. To work out the marketing costs and margins under different channels documented in the study area, ten pre-harvest contractors, ten commission agent cum wholesalers, ten distant market wholesalers, ten retailers and ten exporters were selected from Solapur, Sangola, Pandharpur and Akluj market for the collection of information. Thus, overall fifty market intermediaries were selected to gather the required information.

\section{Marketing channels}

Marketing channels are the path through which goods are moved from the hands of producers to the hand of ultimate consumers. It involves various middlemen who facilitate the flow of goods and services from the producers to the consumers. The length of channel varies from commodity to commodity and depends on the quantity to be moved and the nature and degree of specialization in production.

\section{Marketing cost}

It includes grading and packing charges comprising wages paid to the labour, value of packing material and other charges, includes transport charges, loading and unloading charges and market cost comprising hamali, weighing and commission charges. The total marketing cost (MC) incurred by the producer / seller and by various intermediaries will be calculated as:

$$
\mathrm{MC}=\mathrm{C}_{\mathrm{F}}+\mathrm{C}_{\mathrm{m} 1}+\mathrm{C}_{\mathrm{m} 2}+\mathrm{C}_{\mathrm{m} 3}+\ldots .+\mathrm{C}_{\mathrm{mi}}
$$

Where,

$$
\begin{aligned}
& \mathrm{MC}=\text { Marketing cost, } \\
& \mathrm{C}_{\mathrm{F}}=\text { Cost incurred by Producer, } \\
& \mathrm{C}_{\mathrm{mi}}=\text { Cost incurred by the } \mathrm{i}^{\text {th }} \text { middleman } .
\end{aligned}
$$

\section{Marketing margin}

Marketing margin of middlemen is the difference between the total payment (marketing cost + purchase price) and receipts (sale price) of the middlemen and will be calculated as;

$$
\mathrm{A}_{\mathrm{mi}}=\mathrm{P}_{\mathrm{Ri}}-\left(\mathrm{P}_{\mathrm{Pi}}+\mathrm{C}_{\mathrm{mi}}\right)
$$

Where

$$
\begin{aligned}
& \mathrm{A}_{\mathrm{mi}}=\text { Absolute marketing margin of } \mathrm{i}^{\text {th }} \\
& \text { middlemen, } \\
& \mathrm{P}_{\mathrm{Ri}}=\text { Total value of receipts per unit, } \\
& \mathrm{P}_{\mathrm{Pi}}=\text { Purchase value per unit, } \\
& \mathrm{C}_{\mathrm{mi}}=\text { Cost incurred on marketing per unit. }
\end{aligned}
$$

\section{Price spread}

It is the difference between the price paid by the consumer and price received by the producer for an equivalent quantity.

Price spread: Consumer's price - price received by farmer

Where,

$$
\text { Ps: } \mathrm{Cp}-\mathrm{Pf}
$$

$$
\begin{aligned}
& \mathrm{C} p=\text { consumer's price } \\
& \mathrm{Cf}=\text { price received by farmer }
\end{aligned}
$$

\section{Producers Share in Consumers Rupee}

It is the price received by the farmer expressed as a percentage of the retail price (i.e. price paid by the consumer)

$$
\mathrm{P}_{\mathrm{S}}=\mathrm{P}_{\mathrm{F}} \div \mathrm{Pr}
$$

Where,

$$
\begin{aligned}
& \mathrm{P}_{\mathrm{S}}=\text { Producers Share in Consumers Rupee } \\
& \mathrm{P}_{\mathrm{F}}=\text { Producers price } \\
& \mathrm{Pr}=\text { Retail price }
\end{aligned}
$$

by Acharya and Agrawal, (2001).

\section{Constraints Analysis: Garrett's ranking technique}

Garrett's ranking technique was used to study the opinion of the farmers regarding the major constraints associated with production, marketing and export of pomegranate. As per this method, 
respondents were asked to assign the rank for all factors and the outcomes of such ranking was converted into score value with the help of the following formula:

Percent position $=\frac{100\left(R_{i j}-0.5\right)}{N_{j}}$

Where,

$\mathrm{R}_{\mathrm{ij}}=$ Rank given for the $\mathrm{i}^{\text {th }}$ variable by $\mathrm{j}^{\text {th }}$ respondents and

$\mathrm{N}_{\mathrm{j}}=$ Number of variable ranked by $\mathrm{j}^{\text {th }}$ respondents

The percent position is converted into scores by referring to the table given by Garett and Woodworth (1969). Then for each factor, the scores of each individual was added and then the total value of scores and mean values of score were calculated. These mean scores for all the factors were arranged in descending order and the most influencing factors were identified through the ranks assigned. The factors having highest mean value was considered to be the most important factor.

\section{RESULTS AND DISCUSSION}

\section{Marketing Channels}

The common drill was to sell the fruited pomegranate crop to the pre-harvest contractors who purposively visits the farms before maturity period and after observing the fruited orchard they make a contract with the owner for contract. In the study area maximum farmers show interest to sell their crop to the pre-harvest contractors. This type of auction at the field level itself is named as 'on farm sale'. In a few cases the deal with the pre-harvest contractors was just verbal. In on farm sale token amount was paid as advance at the time of making the contract. Additionally pre-harvest contractor advances loan with or without interest to the farmers whenever they need it. Payments by pre-harvest contractors to farmers was done in installments. Even after the contract was struck, it was the duty of the farmers to take care of the crop, until the crop was harvested. But harvesting of the crop was the responsibility of the pre-harvest contractor. Again they have to take responsibility to transport the produce to the wholesale market and bear the total marketing costs of these operations. The pre-harvest contractors disseminate the produce to the whole sale markets. From this point, pomegranate fruits get distributed through the no of retailers to final consumers. This channel of moving the pomegranate fruits from the farmer's field to the consumers hand was designated as:

Channel-I: Farmer - Pre-harvest contractor -Commission agent cum wholesaler - Retailer -

\section{Consumer}

This was the most common practice followed by majority of the farmers and consequently it was the most preferred channel among all the channels in the study area and the results are in close conformity with the results of Ahire, 2015.

One more way followed by the pomegranate growers in marketing their produce was to sell the produce directly to the distant wholesale markets. From there the produce was moved to the consumers through retailers. This channel of marketing the pomegranate fruits is designated as

Channel-II: Farmer- Distant Market wholesalerRetailer-Consumer

In this channel farmer sold the produce to the distant wholesaler who arrived at the study area from distant places like Hyderabad, Bangalore, Indore, Delhi, Kolkata, Chennai etc. In this channel the harvesting of the crop was the responsibility of the farmers. He was also responsible for transporting the produce to the whole sale market and has to bear the marketing costs incurred in these operations. In the distant wholesale markets, the functions of the commission agent and wholesaler were performed by a single mediator i.e. the distant market wholesaler. After sorting and grading the fruits he sold them to the retailers.

An altered way pursued by the pomegranate growers of Solapur district in marketing their produce was to sell the produce directly to the exporter. In this channel some of the large farmers in the study area took the produce by themselves to the collection point indicated by the exporters and sold it directly to them in anticipation of higher price for their produce.

\section{Channel-III: Farmer - Exporter}

In this channel the harvesting of the crop was 
the responsibility of the producer. He was also responsible for transporting the produce to the collection point indicated by the exporters. He had to bear the costs incurred in these operations. The costs for the marketing of pomegranate fruits were taken by the producer himself when he sold the produce through channel-II and III. When the produce was sold through channel-I i.e., on farm sale to pre-harvest contractors, these costs were beared by the pre-harvest contractor. The percentage of farmers on the preference of marketing channels by pomegranate cultivators in Solapur district is presented in Table 1.

Table 1: Preference of marketing channels by pomegranate cultivators in Solapur district

\begin{tabular}{cccccc}
\hline \multirow{2}{*}{$\begin{array}{c}\text { S1. } \\
\text { No }\end{array}$} & Particulars & \multicolumn{3}{c}{ Categories of growers } & \multirow{2}{*}{ Total } \\
\cline { 3 - 5 } & & Small & Medium & Large & \\
\hline 1 & Channel-I & 32 & & 8 & 64 \\
& & $(56.14)$ & $24(45.28)$ & $(20.00)$ & $(42.67)$ \\
2 & Channel-II & 17 & & 13 & 47 \\
& & $(29.82)$ & $17(32.08)$ & $(32.50)$ & $(31.33)$ \\
3 & Channel-III & & & 19 & \\
& & $8(14.04)$ & $12(22.64)$ & $(47.50)$ & $39(26.00)$ \\
& \multirow{2}{*}{ Total } & 57 & 53 & 40 & 150 \\
& & $(100.00)$ & $(100.00)$ & $(100.00)$ & $(100.00)$ \\
\hline
\end{tabular}

Note: figures in the parentheses indicates the percentage to their total.

It is observed from Table 1 that 42.67 per cent of farmers sold their produce through the channel-I, i.e. with pre-harvest contractor in the study area. Amongst the three categories of pomegranate growers, farmers in small farm category enormously preferred (56.14 per cent) to sell their produce through channel- I, followed by farmers in medium farm category with 45.28 per cent and farmers in large farm category with 20.00 per cent respectively. The pre harvest contractors are the most preferred middlemen by the small farmers than the large farmers because of the facilities offered by them.

Among all the farmers, 31.33 per cent pomegranate growers follow the channel -II. In this channel, 32.50 per cent of pomegranate growers in large farm category preferred channel -II for marketing followed by farmers in medium and large farm category with 32.08 and 29.82 per cent respectively. Pomegranate growers in large farm category preferred channel-III i.e. produce directly sold to exporters at their collection point with 47.50 per cent of the large farmers followed by medium farmers 22.64 per cent and 14.04 per cent small farmers in Solapur district.

\section{Marketing cost incurred by pomegranate growers-seller in the study area}

The marketing cost incurred by the pomegranate growers-seller in the study area was considered when he sold produce through different market intermediaries such as pre-harvest contractor, commission agent, distant wholesaler and exporter in pomegranate marketing. The marketing cost of pomegranate incurred by producer seller includes the costs in harvesting of fruits, cost of packing material used for packing the fruits, the amount spent in transporting the produce from the point of production to the whole sale market and collection point, labour charges for loading and unloading, weighing charges, commission paid to the commission agent and miscellaneous expenses. The details of marketing cost incurred by the grower is given in the Table 2 .

Table 2: Marketing cost incurred by pomegranate growers-seller in the study area

\begin{tabular}{|c|c|c|c|c|c|c|c|}
\hline \multirow{3}{*}{$\begin{array}{l}\text { Sl. } \\
\text { No }\end{array}$} & \multirow{3}{*}{ Particulars } & \multicolumn{6}{|c|}{ Cost incurred by selling to } \\
\hline & & \multicolumn{2}{|c|}{$\begin{array}{c}\text { Pre- } \\
\text { harvest } \\
\text { contractor }\end{array}$} & \multicolumn{2}{|c|}{$\begin{array}{c}\text { Distant } \\
\text { Market } \\
\text { wholesaler }\end{array}$} & \multicolumn{2}{|c|}{ Exporter } \\
\hline & & $\begin{array}{c}\text { ₹/ } \\
\text { tonne }\end{array}$ & $\%$ & $\begin{array}{c}\text { ₹/ } \\
\text { tonne }\end{array}$ & $\%$ & $\begin{array}{c}\text { ₹/ } \\
\text { tonne }\end{array}$ & $\%$ \\
\hline 1 & $\begin{array}{c}\text { Packaging } \\
\text { Material }\end{array}$ & & & 480.00 & 18.40 & - & - \\
\hline 2 & Grading & & & 52.21 & 2.00 & 74.38 & 8.94 \\
\hline 3 & Loading & & & 75.00 & 2.88 & 80.00 & 9.61 \\
\hline 4 & $\begin{array}{c}\text { Transporta- } \\
\text { tion }\end{array}$ & & & 357.20 & 13.69 & 540.11 & 64.91 \\
\hline 5 & Unloading & & & 75.00 & 2.88 & 80.00 & 9.61 \\
\hline 6 & $\begin{array}{l}\text { Weighing } \\
\text { charges }\end{array}$ & & & 25.00 & 0.96 & 25.00 & 3.00 \\
\hline 7 & $\begin{array}{c}\text { Commission } \\
\text { Charges }\end{array}$ & & & 1500.00 & 57.51 & - & - \\
\hline 8 & $\begin{array}{l}\text { Miscel- } \\
\text { laneous } \\
\text { charges }\end{array}$ & & & 44.00 & 1.69 & 32.65 & 3.92 \\
\hline & Total & & & 2608.41 & 100.00 & 832.14 & 100.00 \\
\hline
\end{tabular}

It could be revealed from the Table 2 that in channel-I pomegranate grower sold his produce to pre harvest contractor who bears all the marketing 
cost such as harvesting, transportation, grading, loading and unloading cost etc. instead of the producer. When the produce was sold by channel-II, pomegranate growers sold their produce through the distant market wholesaler and the total cost incurred in the marketing was ₹ 2608.41 per tonne of pomegranate as the commission charges and cost of transportation were bared by pomegranate growers. The major share of cost was commission charges with 57.51 per cent followed by packaging material (18.40 per cent), transportation cost (13.69 per cent), loading unloading charges (2.88 per cent each), grading charges (2.00 per cent) and miscellaneous charges (1.69 per cent). This practice was quietly loss-making to the farmers in the study area as the sale of pomegranates through this channel was costly to the farmer as he bore all costs in marketing the produce. When the produce was sold directly to the exporter at their collection point, the total marketing cost incurred by pomegranate growers was ₹ 832.14 per tonne. Marketing cost incurred by producer on transportation was found to be highest with 64.91 per cent ( $₹ 540.11$ per tonne) followed by loading and unloading charges (9.61 per cent each), grading (8.94 per cent), miscellaneous charges (3.92 per cent) and weighing cost 3.00 per cent. This finding was in contradiction with Koujalagi and Kunnal 1991.

\section{Marketing cost incurred by the intermediaries in the marketing of pomegranates}

The cost incurred by the pre-harvest contractor, commission agent cum wholesaler, distant wholesaler and retailer on various particulars in the marketing of pomegranates is presented in Table $3,4,5$ and 6 .

The details of marketing cost incurred by pre-harvest contractor indicated that they spent about ₹ 1676.99 per tonne towards marketing of pomegranates through channel- I. It could be observed from the table that the major cost incurred by pre-harvest contractor was on commission charges with ₹ 540 per tonne constituting 32.20 per cent. Next in order was packaging material cost with ₹ 340 per tonne sharing about 20.27 per cent of the total marketing cost followed by transportation cost (16.70 per cent), harvesting cost 14.91 per cent, loading and unloading (4.47 per cent each), grading (3.03 per cent), miscellaneous expenses (2.46 per cent) and weighing cost ₹ 25 per tonne. Similar results were found by Jadhav et al. (2012) and Sudharshan (2012).

Table 3: Marketing cost incurred by Pre-harvest contractor in the marketing of pomegranates

\begin{tabular}{cccc}
\hline $\begin{array}{c}\text { S1. } \\
\text { No }\end{array}$ & Particulars & $\begin{array}{c}\text { ₹ per } \\
\text { tonne }\end{array}$ & Percentage \\
\hline 1 & Harvesting cost & 250.00 & 14.91 \\
2 & Packaging Material & 340.00 & 20.27 \\
3 & Grading & 50.74 & 3.03 \\
4 & Loading & 75.00 & 4.47 \\
5 & Transportation & 280.00 & 16.70 \\
6 & Unloading & 75.00 & 4.47 \\
7 & Weighing charges & 25.00 & 1.49 \\
8 & Commission Charges & 540.00 & 32.20 \\
& Miscellaneous charges & 41.25 & 2.46 \\
& Total & $\mathbf{1 6 7 6 . 9 9}$ & $\mathbf{1 0 0 . 0 0}$ \\
\hline
\end{tabular}

Table 4: Marketing cost incurred by commission agent cum wholesaler in the marketing of pomegranates

\begin{tabular}{cccc}
\hline $\begin{array}{c}\text { S1. } \\
\text { No }\end{array}$ & Particulars & $\begin{array}{c}\text { ₹ per } \\
\text { tonne }\end{array}$ & Percentage \\
\hline $\mathbf{1}$ & Labour cost & 170.00 & 13.39 \\
2 & Cost of storage & 84.40 & 6.65 \\
3 & Storage loss (2\% of & 850.00 & 66.95 \\
& produce) & & \\
4 & License fee & 30.00 & 2.36 \\
5 & Shop rent & 50.00 & 3.94 \\
$\mathbf{6}$ & Miscellaneous charges & 85.21 & 6.71 \\
& Total & $\mathbf{1 2 6 9 . 6 1}$ & $\mathbf{1 0 0 . 0 0}$ \\
\hline
\end{tabular}

As evident from Table 4, the marketing cost incurred by commission agent cum wholesaler was ₹ 1269.61 per tonne of which storage loss (66.95 per cent) alone formed a major component. The other important costs were labour cost, storage cost, license fee, shop rent and miscellaneous expenses etc., which together came to ₹ 419.61 per tonne constituting 33.05 per cent.

Table 5: Marketing cost incurred by distant wholesaler in the marketing of pomegranates

\begin{tabular}{cccc}
\hline $\begin{array}{c}\text { S1. } \\
\text { No }\end{array}$ & Particulars & $\begin{array}{c}\text { ₹ per } \\
\text { tonne }\end{array}$ & Percentage \\
\hline $\mathbf{1}$ & Labour cost & 70.50 & 6.80 \\
2 & $\begin{array}{c}\text { Cost of storage } \\
\text { Storage loss (2\% of } \\
\text { produce }\end{array}$ & 51.17 & 4.93 \\
& 813.20 & 78.38
\end{tabular}




$\begin{array}{cccc}4 & \text { License fee } & 20.00 & 1.93 \\ 5 & \text { Shop rent } & 50.00 & 4.82 \\ 6 & \text { Miscellaneous charges } & 32.64 & 3.15 \\ & \text { Total } & \mathbf{1 0 3 7 . 5 1} & \mathbf{1 0 0 . 0 0}\end{array}$

Marketing cost incurred by distant wholesaler in the marketing of pomegranates is presented in table 5 . The total cost incurred by distant wholesaler was found to be ₹ 1037.51 per tonne. Storage losses formed a major component with ₹ 813.20 per tonne (78.38 per cent) followed by other important costs like labour cost, storage cost, license fee, shop rent and miscellaneous expenses etc., which together came to ₹ 224.31 per tonne constituting 21.62 per cent. Similar results were found by Nair et al. 2017.

Table 6: Marketing cost incurred by retailer in the marketing of pomegranates

\begin{tabular}{cccc}
\hline $\begin{array}{c}\text { Sl. } \\
\text { No }\end{array}$ & Particulars & $\begin{array}{c}\text { ₹ per } \\
\text { tonne }\end{array}$ & Percentage \\
\hline $\mathbf{1}$ & Transportation & 128.25 & 7.74 \\
2 & Loading and Unloading & 140.00 & 8.45 \\
3 & Municipality charge & 50.00 & 3.02 \\
4 & Storage loss (3\% of & & \\
& produce) & 1280.81 & 77.33 \\
5 & Miscellaneous charges & 57.24 & 3.46 \\
& Total & $\mathbf{1 6 5 6 . 3 0}$ & $\mathbf{1 0 0 . 0 0}$ \\
\hline
\end{tabular}

The retailer is the last link in the distribution channel and marketing cost incurred by him is presented in Table 6. He incurred on an average an expenditure of ₹1656.30 for marketing one tonne of pomegranate. Of this major portion went towards storage losses with 77.33 per cent (₹ 1280.81). Next in order were loading unloading and transportation costs with 8.47 and 7.74 per cent respectively.

\section{Marketing margins and price spread in the marketing of pomegranates}

The marketing margin and price spread in marketing of pomegranate for different marketing channels in the study area is presented in Table 7.

\section{Marketing Costs, margins and price spread in Channel-I, Channel-II and Channel-III}

Marketing costs and margins of the intermediaries involved in the marketing of pomegranate indicated that the producer's share in consumer's rupee in channel-I was 62.99 per cent after deducting the costs and margins of the intermediaries involved in the channel. The total marketing cost incurred by pre harvest contractor accounted for 2.57 per cent of consumer's price. The total marketing cost incurred by commission agent-cum-wholesaler and retailer amounted to ₹ 1269.61 per ton and ₹ 1656.30 per ton respectively. The price spread in first channel was ₹ 24145.25 (37.01 per cent). The net price received by the producer seller accounted for ₹ 41100 (62.99 per cent). The profit shares of the pre harvest contractors was ₹ 4588.03 (7.03 per cent), commission agent cum wholesalers was ₹9620.08 (14.74 per cent) and Retailers was ₹ 5334.24 (8.18 per cent) respectively. This was the most popular channel of marketing in the study area, since in this channel the net price received by the producer was higher than channel - II and the pre-harvest contractor arrived to production point thus saving the time and transportation cost of the producerseller and also due to advance payment paid by the pre-harvest contractor before taking the delivery of the produce. Similar results were found by Ravikumar et al. (2015) and Sudharshan et al. (2013).

The producer's share in consumer's rupee in channel-II was 58.04 per cent after deducting the costs and margins of the intermediaries involved in the channel. The net price received by the producerseller in this channel was ₹ 38051.59 (54.32 per cent) after deducting the marketing cost of ₹ 2608.41 (3.72 per cent) per ton incurred by him. The total marketing cost incurred by distant-wholesaler and retailer amounted to ₹ 1037.51 per ton and ₹ 1656.30 per ton respectively. The price spread in channel -II was ₹ 29394.36 (41.96 per cent). The profit shares of the distant market wholesaler was ₹ 10656.78 (15.21 per cent) and Retailers was ₹ 8183.59 (11.68 per cent) respectively. In channel- III the cost of marketing incurred by the producer was ₹ 832.14 per ton (1.85 per cent) as the produce was to be transported to the exporter's collection point from the production places. In this channel the net price received by the producer was ₹ 44167.87 per ton accounting for 98.15 per cent, which was marginally high compared to channel-I and II.

\section{Constraints faced in marketing of pomegranate}

The problems faced in marketing of pomegranates are presented in Table 8 . According to results 14 constraints have been reported by the pomegranate growers. 
Table 7: Marketing Costs, margins and price spread in different channels of pomegranate marketing in Solapur district

₹/tonne

\begin{tabular}{|c|c|c|c|c|c|c|c|}
\hline \multirow{2}{*}{$\begin{array}{l}\text { Sl. } \\
\text { No }\end{array}$} & \multirow[t]{2}{*}{ Particulars } & \multicolumn{2}{|c|}{ Channel-I } & \multicolumn{2}{|c|}{ Channel-II } & \multicolumn{2}{|c|}{ Channel-III } \\
\hline & & ₹ & $\%$ & $₹$ & $\%$ & $₹$ & $\%$ \\
\hline 1 & Price received by the producer & 41100 & 62.99 & 40660 & 58.04 & 45000 & 100.00 \\
\hline 2 & Marketing cost of producer & - & - & 2608.41 & 3.72 & 832.14 & 1.85 \\
\hline 3 & Net price received by producer & 41100 & 62.99 & 38051.59 & 54.32 & 44167.86 & 98.15 \\
\hline \multirow[t]{5}{*}{4} & Acquiring cost by & & & & & & \\
\hline & a) Pre harvest contractor & 41100 & 62.99 & - & - & - & - \\
\hline & b) Commission agent cum wholesaler & 47365.02 & 72.60 & - & - & - & - \\
\hline & c) Distant wholesaler & - & - & 48520.18 & 69.26 & - & - \\
\hline & d) Retailer & 58254.71 & 89.29 & 60214.47 & 85.95 & - & - \\
\hline \multirow[t]{5}{*}{5} & Marketing cost for & & & & & & \\
\hline & a) Pre harvest contractor & 1676.99 & 2.57 & - & 0.00 & - & - \\
\hline & b) Commission agent cum wholesaler & 1269.61 & 1.95 & - & 0.00 & - & - \\
\hline & c) Distant wholesaler & - & - & 1037.51 & 1.48 & - & - \\
\hline & d) Retailer & 1656.30 & 2.54 & 1656.30 & 2.36 & - & - \\
\hline \multirow[t]{5}{*}{6} & Profit for & & & & & & \\
\hline & a) Pre harvest contractor & 4588.03 & 7.03 & - & - & - & - \\
\hline & b) Commission agent cum wholesaler & 9620.08 & 14.74 & - & - & - & - \\
\hline & c) Distant wholesaler & - & - & 10656.78 & 15.21 & - & - \\
\hline & d) Retailer & 5334.24 & 8.18 & 8183.59 & 11.68 & - & - \\
\hline 8 & Purchase price of consumer & 65245.25 & 100.00 & 70054.36 & 100.00 & - & - \\
\hline 9 & Marketing Margin/ price spread & 24145.25 & 37.01 & 29394.36 & 41.96 & - & - \\
\hline 10 & Producers share in consumers rupee & & 62.99 & & 58.04 & & \\
\hline
\end{tabular}

(The channel-III were traced only up to the level of exporter).

Table 8: Garrett's ranking for Constraints in Marketing of Pomegranates

\begin{tabular}{cccc}
\hline Sl. No. & Constraints & Mean Score & Rank \\
\hline 1 & Not getting remunerative price for the produce & 83.48 & $\mathrm{I}$ \\
2 & Fruit auction is not transparent & 74.25 & $\mathrm{II}$ \\
3 & High cost of transportation & 69.17 & $\mathrm{III}$ \\
4 & High commission charges & 62.02 & $\mathrm{IV}$ \\
5 & Lack of market or price information & 58.60 & $\mathrm{~V}$ \\
6 & Low price paid to farmers. & 55.55 & $\mathrm{VI}$ \\
7 & Transport Facility & 52.20 & VII \\
8 & Lack of Storage Facility & 48.73 & VIII \\
9 & Fluctuations in Market Price & 40.80 & $\mathrm{IX}$ \\
10 & Skilled Labour Facilities & 37.63 & $\mathrm{X}$ \\
11 & Risk Bearing & 33.85 & $\mathrm{XI}$ \\
12 & Timely Payment & 32.91 & $\mathrm{XII}$ \\
13 & Lack of Processing Facilities & 25.53 & $\mathrm{XIII}$ \\
14 & Fruit Spoilage due to damage During transportation & 24.28 & $\mathrm{XIV}$ \\
\hline
\end{tabular}


The results from the table 8 reveals that majority of the farmers have opined that they are not getting remunerative price for the produce hence, it ranks first with the highest Garrett score 83.48 followed by fruit auction which is not transparent, higher transportation costs when fruits are sold outside the local area, high commission charges, lack of market information and low price paid to farmers accounting second, third, fourth, fifth and sixth position with Garrett scores 74.25, 69.17, 62.02, 58.60 and 55.55 respectively. Transport facility, lack of storage facility, fluctuations in market price etc., were some of the constraints also reported by the pomegranate growers in the study area. Similar results were found by Adsul et al. 2013 and Patil et.al. 2016.

\section{CONCLUSION AND IMPLICATIONS}

The study concludes that pomegranate growers reported the marketing channels involving preharvest contractors and commission agent cum wholesalers for disposal of their produce to be the most preferred channel since this channel assured greater share in consumer rupee. Some farmers sold their produce directly to the exporters. It was also concluded from the study that the major constraints faced by pomegranate growers in study area were farmers not getting remunerative price for their produce, cheating by middlemen's, higher transportation costs when fruits are sold outside the local area, high commission charges, lack of market information and low price paid to farmers. With the help of the above study the researcher tried to understand the related problems of pomegranate producers. Conclusions of this study will be helpful to pomegranate growers and agencies who are engaged in production and marketing of pomegranate for designing future policies. Farmers themselves may transport pomegranate in the nearby wholesale market, hence reducing marketing margin and increasing their profits. It has been noticed that the marketing cost of pomegranates in study area was higher, thus, there is a need to establish institutional agencies that can advance credit to pomegranate growers and encourage them to market their produce themselves. A marketing co-operative society may be established exclusively for the marketing of pomegranate to rescue the farmers from exploitation by the marketing agents or intermediaries. There is a need of demand driven pomegranate markets rather than supply driven and price of the produce should be based on the cost of cultivation of that crop rather than the prevailing wholesale price that exists in the market. The pomegranate markets growers should be their own price setters and not price followers.

\section{REFERENCES}

Acharya, S.S. and Agrawal, N.L. 2001. Agricultural Marketing in India, Oxford \& IBH Publishing Company, New Delhi.

Adsul, G.B., Khalge, M.I. and Suradkar, D.D. 2013. Constraints and suggestion made by the pomegranate growers for adoption of improved practices for control measures of oily spot disease. Agriculture Update, 8(4): 609-612.

Ahire, S.C. 2015. An analysis of market channel of Pomegranate fruit in Dhule district (M.S.). International Journal of Science and Research, 6(2): 1112-1116.

Garett, H.E. and Woodworth, R.S. 1969. Statistics in psychology and education. Vakils, Feffer and Simons Pvt. Ltd., Bombay, pp. 329.

Kaujalagi GMS. B. and Kunnal, L.B. 1991. Marketing of Pomegranate Fruits. Indian Journal of Agricultural Marketing, 15(2): 189.

Khunthe, Y.N. 2006. 'Principal of Horticulture and fruit growing', A. D. H. Publication, New Delhi, pp. 182-185.

Kohansal, M.R. and Rahimi, M. 2013. Investigating factors marketing pomegranate in Fars. International Journal of Agronomy and Plant Production, 4(10): 2759-2763.

Ladaniya, M.S., Wanjari, V. and Mahale, B. 2003. 'Price Spread of Pomegranate', Indian Journal of Agricultural Economics, 58(4): 800-811.

Patil, S.B, Katole, R.T, Mankar, D.M, More, G.B. and Wankhade, P.P. 2016. Socio-Economic Transformation due to Adoption of Recommended Cultivation Practices of Pomegranate. PKV Research Journal, 40(1): 84-91.

Ravikumar, K.T., Hosamani, S.B. and Mamle Desai, N.R. 2015. Resource Use Efficiency and Marketing Channels for Pomegranate in Chitradurga District of Karnataka, India: an Economic Analysis. III Id International Seminar on Pomegranate and Minor Mediterranean Fruits. Acta Hort. 1089, ISHS 2015, Proceedings 229-236.

Sudharshan, G.M. 2012. Economic Appraisal of Pomegranate Production and Marketing in Chitradurga District of Karnataka. International Conference on Challenges and Opportunities in Mechanical Engineering, Industrial Engineering and Management Studies (ICCOMIM). 1047-1050.

Sudharshan, G.M., Anand, M.B. and Sudulaimuttu 2013. Marketing \& Post-Harvest Losses in Fruits: Its Implications on Availability \& Economy - A Study on Pomegranate in Karnataka. International Journal of Management and Social Sciences Research, 2(7): 34-43. 